\title{
BREACH OF FIDUCIARY DUTY INVOLVING FULL DIRECTOR KNOWLEDGE HELD 10b-5 VIOLATION
}

IN Schoenbaum v. Firstbrook $k^{1}$ the Court of Appeals for the Second Circuit, sitting en banc, has ruled that a plaintiff bringing a derivative suit states a cause of action under section $10(\mathrm{~b})$ of the Securities Exchange Act of $1934^{2}$ and rule $10 \mathrm{~b}-5^{3}$ when the complaint alleges a conspiracy between the corporation's entire board of directors and the controlling stockholder to sell treasury stock to the controlling stockholder at less than what all of the corporation's directors know to be the shares' true value. The court further held that summary judgment should not be granted for the defendants in such an action without at least allowing the plaintiff to utilize discovery procedures since otherwise the plaintiff will be unable to rebut the defendants' affidavits denying conspiracy based on facts exclusively within the defendants' possession. In early 1964, Aquitaine Company, a "subsidiary" of a French governmental agency, ${ }^{4}$ acquired control of Banff Oil Ltd., a Canadian corporation whose stock is registered with the SEC and traded on both the American and the Toronto Stock Exchanges. In October of the same year Aquitaine and Banff agreed to carry out joint oil explorations on a large tract of land in the Rainbow Lake area of Alberta, Canada. ${ }^{5}$ On December 11, 1964, Banff's board of directors, the three Aquitaine representatives abstaining, voted to sell 500,000 shares of Banff treasury stock to Aquitaine at the current market price. Shortly thereafter Aquitaine accepted Banff's offer, although actual delivery of the stock did not take place until March 16, 1965.

1405 F.2d 215 (2d Cir. 1968).

215 U.S.C. $\$ 78 \mathrm{j}(\mathrm{b})(1964)$.

317 C.F.R. \& 240.10b-5 (1968).

- Aquitaine is a wholly owned subsidiary of Societe National des Petroles d'Aquitaine, a French corporation which is in turn a subsidiary of Enterprises for Research and Activities in Petroleum, a French governmental oil agency. Schoenbaum v. Firstbrook, 405 F.2d 200, 204 (2d Cir. 1968).

s Banff and Aquitaine obtained a 50\% interest in 160,000 acres of oil land in the Rainbow Lake area from Socony Mobil in exchange for their promise to pay the total cost of drilling two exploratory wells. Oil exploration had been carried on in the area before but had proven unfruitful-at least sixteen unsuccessful exploratory wells had been drilled previous to the Banff-Aquitaine attempt. $I d$. 
Exploration in the Rainbow area began in late 1964 and the first test well flowed in arly 1965. Sometime subsequent to the discovery of the oil, Banff issued a press release disclosing its exploration activity, but, pursuant to Alberta law, Banff withheld information concerning the extent of the discovery to reduce competition from other companies in bidding on governmental oil lands in the discovery area. ${ }^{6}$ Further exploration disclosed that the oil find was extensive and that it would be necessary to build a pipeline into the area. In September 1965 Banff directors voted to negotiate the sale of 270,000 shares of treasury stock in order to finance its share of the pipeline construction cost. Paribas Corporation, a wholly-owned subsidiary of a French banking institution, ${ }^{7}$ made a written offer on November 22, 1965, to purchase the shares at the then prevailing market price. Banff accepted the offer and delivery took place January 24, 1966. It was not until March 16, 1966. that full disclosure was made as to the extent of Banff's oil discovery. An American shareholder of Banff brought a derivative suit against Aquitaine, Paribas and the Banff directors, alleging that the defendants had conspired to defraud Banff by causing the corporation to sell treasury shares for an inadequate consideration. ${ }^{8}$ The defendants moved for summary judgment and submitted affidavits categorically denying the existence of any conspiracy. While rejecting the defendant's claims that at the time of the transaction they did not know of the oil discovery, ${ }^{9}$ the trial court felt that under rule 56(e) of the Federal

\footnotetext{
- Plaintiff conceded that the defendants were not in violation of any securities laws or in breach of their fiduciary duty in withholding the information as to the extent of Banff's oil discovery. Id. at 213 n. 10.

'Paribas Corporation is a Delaware corporation doing business in New York and is a wholly owned subsidiary of Banque de Paris et des Pays-Bas, a French banking institution. Paribas negotiated the purchase of Banfr's stock on behalf of another subsidiary of Banque de Paris. Id. at 205.

${ }^{8}$ The Banff-Aquitaine transaction involved the payment by Aquitaine of $\$ 1.35 \mathrm{pcr}$ share-the closing price of Banff common stock on the Toronto Stock Exchange on December 11, 1964. The Banff-Paribas transaction involved the payment by Paribas of $\$ 7.30$ per share-the Toronto price of Banff common stock on November 22, 1965. Banff common stock traded at prices ranging as high as $\$ 18$ pcr share in 1966 after the public disclosure of the oil discovery. $1 d$. at 205 \& n.1.

- In his dissent to the en banc opinion, Judge Medina pointed out that the district court's rejection of defendants' claims that they did not know of the oil discovery at the time of the Banff-Aquitaine transaction was not based on any factual finding by the district court. Rather the lower court judge had assumed arguendo, in making his ruling on the defendants
} 
Rules of Civil Procedure, the plaintiff's allegation of conspiracy was overcome by the defendants' denial supported by affidavits, since the plaintiff's allegations were not buttressed by an affidavit made on his own personal knowledge. ${ }^{10}$ Therefore, after denying the plaintiff's request to carry out a program of discovery, the district court granted summary judgment for the defendants on the grounds that (1) the court did not have jurisdiction, and (2) the plaintiff's complaint, absent the conspiracy allegation which was nullified by the failure to properly respond under rule $56(\mathrm{e})$ to the defendants' affidavits, did not state a claim under section $10(\mathrm{~b})$. In a threejudge panel opinion the Second Circuit disagreed with the district court as to the jurisdictional question, " but affirmed the decision because of the rule $56(\mathrm{e})$ determination. ${ }^{12} \mathrm{~A}$ petition for rehearing en banc was granted in order to reconsider whether the defendants were entitled to summary judgment under rule 56 . The Second Circuit en banc affirmed the lower court's granting of summary judgment only as to the Paribas Corporation, reversing as to all other defendants, ${ }^{13}$ and remanding to the district court for discovery

motion for summary judgment, that the plaintiff's action must fail even if the defendants had known of the oil discovery. Schoenbaum v. Firstbrook, 268 F. Supp. 385, 394 \& n.4 (S.D.N.Y. 1967). The en banc dissenter felt that this "contrary-to-fact" assumption had colored the entire case. 405 F.2d at 220 . (Medina, J., dissenting).

${ }^{10} 268$ F. Supp. 385 (S.D.N.Y. 1967). See also FED. R. Civ. P. 56(e) (when motion for summary judgment is supported by affidavit, adverse party may not rest on his pleadings but must respond by affidavit on personal knowledge, showing that there is a genuine issue for trial).

"Plaintiff predicated subject matter jurisdiction upon section 27 of the Securities Exchange Act of 1934. 15 U.S.C. $\$ 78$ aa (1964) gives federal courts exclusive jurisdiction over all "actions at law brought to enforce any liability or duty created by this chapter or the rules and regulations thereunder." The district court conceded that the Securities Exchange Act had no cxtraterritorial application and that, since all of the transactions complained of took place in Canada, the court did not have subject matter jurisdiction. 268 F. Supp. at 391-94. In reversing the lower court's ruling, the panel court looked to the fact that Banff was registered with the SEC and that its stock was sold on the American Stock Exchange. The court ruled that the act did have extraterritorial application because the act was intended to protect domestic investors who have purchased foreign securities on American exchanges. Noting that acts consummated outside the territory of the United States but having a detrimental affect on American exchanges are of legitimate concern to the United States, the court cited Strassheim v. Dailey, 221 U.S. 280, 285 (1911), where the Supreme Court stated: "Acts done outside a jurisdiction, but intended to produce and producing detrimental effects within it, justify a state in punishing the cause of the harm as if [the aetor] had been present at the [time of the detrimental] effect, if the state should succeed in getting him within its power." 405 F.2d at 206. The en banc court adopted the panel court's jurisdictional ruling. $405 \mathrm{~F} .2 \mathrm{~d}$ at 217.

12405 F.2d at $209-10$.

13 Id. at 217. 
proceedings. The court thereby at least implied that if evidence could be obtained to support the allegations of a conspiracy, a 10b5 derivative claim could be sustained even though full director knowledge was involved.

Rule 10b-5 makes it unlawful for any person to employ any artifice, scheme, or device to defraud; to state, or to fail to state, any material fact which, with regard to the surrounding circumstances, would be misleading; or to participate "in any act, practice, or course of business which operates or would operate as a fraud or deceit upon any person, in connection with the purchase or sale of any security." $"$ Although the rule does not expressly provide for civil liability, since Kardon v. National Gypsum Co.15 the courts have held that civil redress is available to a defrauded claimant. Further, 10b-5 claimants have not been subjected to a rigid adherence to the common law elements of fraud. ${ }^{16}$ Courts, to varying degrees, have modified or abandoned such traditional fraud requirements as privity, ${ }^{17}$ scienter ${ }^{18}$ and reliance. ${ }^{19}$ The application of $10 \mathrm{~b}-5$ to shareholder derivative suits, however, has created difficulties in devising a consistent rationale for determining the circumstances under which a breach of fiduciary duty by corporate insiders will be considered within the ambit of rule 10b-5."

4 17 C.F.R. \$ 240.10b-5 (1968).

1569 F. Supp. 512 (E.D. Pa. 1946), modified, 73 F. Supp. 798 (E.D. Pa.), inodified, 83 F. Supp. 613 (E.D. Pa. 1947).

${ }^{16}$ See, e.g., Stevens v. Vowell, 343 F.2d 374, 379 (10th Cir. 1965).

${ }^{17}$ See Cochran v. Channing Corp., 211 F. Supp. 239, 243-44 (S.D.N.Y. 1962). Sec generally Comment, Civil Liability under Section IOB and Rule IOB-5: A Suggestion for Replacing the Doctrine of Privity, 74 YALE L.J. 658 (1965).

"See Ellis v. Carter, 291 F.2d 270, 274 (9th Cir. 1961); Texas Continental Life Ins. Co. v. Bankers Bond Co., 187 F. Supp. 14 (W.D. Ky. 1960), rev'd on other grounds sub nom. Texas Continental Life ins. Co. v. Dunne, 307 F.2d 242 (6th Cir. 1962) (scienter not required). But see Weber v. C.M.P. Corp., 242 F. Supp. 321 (S.D.N.Y. 1965): Trussell v. United Underwriters, Ltd., 228 F. Supp. 757 (D. Colo. 1964) (scienter required); cf. Dack v. Shanman, 227 F. Supp. 26 (S.D.N.Y. 1964). See generally. Note, Proof of Scienter . lecessary in a Private Suit Under SEC Anti-Fraud Rule 10b-5, 63 Mich. L. REv. 1070 (1965).

In a section 11-type action brought under 10b-5 it is arguably more reasonable to require scienter, since otherwise section 11 coverage would merely be duplicated without the same procedural limitations.

${ }^{15}$ See. e.g., Speed v. Transamerica Corp., 99 F. Supp. 808 (D. Del. 1951); Ruder, (ivil Liability. Under Rule l(1)b-5: Judicial Revision of Legislative Intent? 57 Nw. U.L. Rev. 627, 678 (1963).

20 See generally Note, Fiduciary Suits L'uder Rule lob-5. 1968 Dukf L.J. 791. 
The confusion surrounding the application of $10 \mathrm{~b}-5$ to derivative actions has roots in two Second Circuit decisions promulgated within the same month. In $O^{\prime}$ Neill v. Maytag ${ }^{21}$ wherein the plaintiff alleged that the corporate directors, in an effort to maintain their control, negotiated an exchange of stocks with another corporation at an unfavorable ratio, the court stated that, since all of the directors of both corporations involved in the transaction had full knowledge of the unfair exchange, there was no element of deceit which could give rise to a $10 \mathrm{~b}-5$ violation. The court relied upon the holding of Birnbaum v. Newport Steel Corp..$^{22}$ to the effect that $10 \mathrm{~b}-5$ does not apply to "fraudulent mismanagement of corporate affairs" ${ }^{23}$ but only to actual fraud associated with thc sale or purchase of securities. ${ }^{24}$ The deceit requirement in Maytag is difficult to reconcile with the court's earlier dicta in Ruckle v. Roto American Corp..${ }^{25}$ stating that even if all directors of the corporation had becn informed of a stock issuance at less than fair value, the corporation could still be considered the victim of fraud under rule $10 \mathrm{~b}-5 .{ }^{26}$ Although decisions which followed Maytag and Ruckle seemed to pursue somewhat divergent paths, the liberal Ruckle dicta was subsequently expanded in A.T. Brod \& Co. v. Perlow and Vine v. Beneficial Finance Corp. ${ }^{28}$ In both Brod and Vine the Second Circuit, without explicitly identifying any element of deceit, construed 10b-5 to prohibit all "fraudulent schemes" in connection with the purchase or sale of securities. ${ }^{29}$ The Second Circuit's failure to articulate an explicit fraud test recently led a district court in Entel v. Allen ${ }^{30}$ to assert that Vine and Brod could be interpreted as extending the purview of $10 \mathrm{~b}-5$ to an undisclosed breach of state law fiduciary duty.

In the Schoenbaum panel decision ${ }^{31}$ the Second Circuit

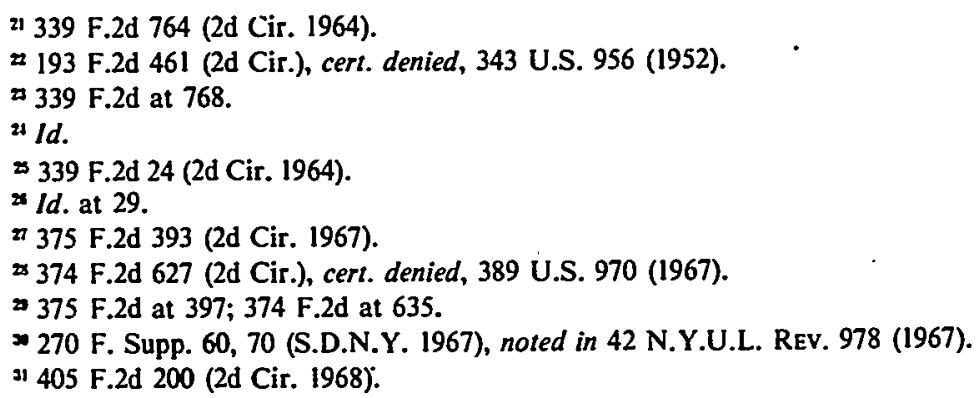


majority, after reiterating the Maytag rule that deceit is prerequisite to a $10 \mathrm{~b}-5$ violation, reasserted and clarified the Ruckle dicta that a corporation may be deceived by its entire board of directors. Whereas Ruckle only alluded to the possibility of such a deceptive transaction, ${ }^{32}$ the Schoenbaum court stated unequivocally:

[A] corporation may be defrauded [in violation of rule 10b-5] . . . even when all of its directors know all of the material facts, if the conflict between the interests of one or more of the directors and the interests of the corporation prevents the effective transmission of material information to the corporation .....33

The majority of the Schoenbaum panel court, however, felt itself precluded from finding a conflict of interest between Banff and its directors because of the plaintiff's failure to respond properly to the defendants' affidavits which categorically denied the existence of any such conspiracy. Thus, the plaintiff's procedural failing resulted in a complaint effectively alleging merely "arm's length transactions' ${ }^{34}$ in which the non-interested directors had conveyed treasury shares at less than their true value. Since the court found that the affidavits conclusively established that the directors did not conspire with the purchasers, there was no adverse interest on the part of the Banff directors which would prevent their knowledge from being imputed to the corporation. The dissenter in Schoenbaum, desiring an interpretation of $10 \mathrm{~b}-5$ fraud which would encompass stock transactions in which the directors deceive the shareholders, stated that the majority's appellation of "arm's length transactions" to the stock sales was unrealistic since the abstention of the Aquitaine directors amounted to nothing more than an "empty ceremonial." "' Implicit in the dissenter's rationale is the desire to expand the "fraudulent scheme" test of Vine and $B r o d^{36}$ to include traditional breaches of fiduciary duty in securities transactions.

In deciding the merits of Schoenbaum, the en banc court employed a two-step analysis by first considering the summary

\footnotetext{
32339 F.2d at 29.

405 F.2d at 211-12.

H Id. at 211.

5 Id. at 215 n.2.

ss See note 29 supra and accompanying text.
} 
judgment ruling of the lower court and then turning its attention to the question of whether a triable claim was stated under rule 10b-5. On the summary judgment issue, the Second Circuit majority reversed the district court's ruling for the directors of Banff and Aquitaine and remanded the case with the order that the plaintiff be allowed to use discovery procedures in order to bolster his conspiracy allegations. ${ }^{37}$ Stating that summary judgment should rarely be granted against a plaintiff in a stockholder's derivative action unless the plaintiff has been allowed discovery, the court's main consideration was that in a case of an alleged conspiracy, the facts are exclusively in the possession of the defendants, effectively foreclosing the plaintiff's opportunity to counteract the defendants' affidavits if discovery is denied..$^{38}$ The court further stated that where, as here, the case involves issues as to the knowledge, intent and motive of the defendants, a full trial might be required in order to give the trier of fact an opportunity to observe the demeanor of the witnesses. ${ }^{39}$

Assuming that plaintiff might substantiate his conspiracy

${ }^{\pi} 405$ F.2d 215, 218 (2d Cir. 1968). In Schoenbaum the plaintiff's response to defendants' affidavits in support of their summary judgment motion consisted of only an affidavit by his attorney-a response clearly insufficient under rule 56(e). See note 10 supra. Frequently, however, a plaintiff will be unable to state that he has personal knowledge of the conspiracy; he will only know those facts which lead him to believe that there was a conspiracy. Therefore, when a "Schoenbaum" plaintiff is confronted with defense affidavits supporting a motion for summary judgment, he should proceed under rule $56(f)$, whieh permits the party opposing summary judgment to set forth reasons why he is unable to present evidentiary affidavits justifying his opposition. See generally 6 J. Moore, Federal Practice I 56.24, at 2871 (2d ed. 1966). Although a genuine issue of the defense affidavits' credibility is not raised by a mere showing that the affiants are interested in the outcome of the litigation, see, e.g., Note, Summary Judgment Under Federal Rule of Civil Procedure 56-A Need for a Clarifying Amendment, 48 lowA L. REv. 453, 462-63 (1963), it would seem that Schoenbaum could have effectively challenged the affiant's credibility by forcefully illuminating the allegations of his original complaint.

${ }^{*}$ See. e.g., Subin v. Goldsmith, 224 F.2d 753 (2d Cir.), cert. denied, 350 U.S. 883 (1955); Colby v. Kune, 178 F.2d 872 (2d Cir. 1949); Fogelson v. Am. Woolen Co., 170 F.2d 660 (2d Cir. 1948). See also 6 J. Moore, Federal Practice 1 56.17[60], at 2675 (2d ed. 1966).

see, e.g., Subin v. Goldsmith, 224 F.2d 753, 757 (2d Cir.), cert. denied, 350 U.S. 883 (1955). See also Poller v. CBS, 368 U.S. 464, 473 (1962) ("We believe that summary procedures should be used sparingly in complex antitrust litigation where motive and intent play leading roles, the proof is largely in the hands of the alleged conspirators, and hostile witnesses thicken the plot."); Cross v. United States, 336 F.2d 431, 434 (2d Cir. 1964); Alvado v. Gen. Motors Corp., 229 F.2d 408, $411-12$ (2d Cir. 1955), cert. denied, 35I U.S. 983 (1956). 
allegations by his program of discovery, the en banc court next considered the issue of whether a claim had been stated under rule 10b-5. The court ruled that, as to Paribas, the plaintiff had failed to allege any such violation..$^{40}$ In affirming the lower court's dismissal of Paribas, the en banc court ascribed significance to the plaintiff's failure to allege (1) that 'Paribas was in possession of information not available to Banff and (2) that Paribas was in a position, through ownership of stock or otherwise,"1 to conspire with or influence the judgment of the Banff directors by any improper means. The plaintiff's failure to show any connection between the Banff directors and Paribas resulted in the court's acceptance of the transaction as being negotiated at arm's length. In finding that the plaintiff's allegations were sufficient to state a claim under $10 \mathrm{~b}-5$ as against Aquitaine and Banff's directors, however, the court restated the Ruckle dicta that "a majority or even the entire board of directors may be held to have defrauded their corporation.' '42 Whereas the Schoenbaum panel court utilized an imputed-knowledge test under which the directors' knowledge is not imputed to the "deceived" corporation in situations where the entire board has an interest adverse to that of the corporation, ${ }^{33}$ the en banc court saw no need to articulate such a complex rationale for explaining how a corporation could be deceived by all of its managing agents. The 10b-5 violation was found in that Aquitaine, the controlling stockholder, caused treasury stock to be sold to it for an inadequate consideration, clearly a traditional breach of fiduciary duty. Such use of controlling influence, if proven, would be found to constitute a violation of subdivision (3) of $10 \mathrm{~b}-5$ because Aquitaine engaged in an "act, practice or course of business which operate[s] or would operate as fraud or deceit upon any person, in connection with the purchase or sale of any security." 44

An additional basis ${ }^{15}$ for the imposition of liability was the

\footnotetext{
s0 405 F.2d at 219.

"See note 53 infra.

2405 F.2d at 219.

is 1 . at $211-14$.

417 C.F.R. $\$ 240.10 b-5(c)$ (1964).

is In turning its attention to Pappas, the en bane majority stated: “Moreover, Aquitaine and the directors of Banff were guilty of deceiving the stockholders of Banff (other than Aquitaine)." 405 F.2d at 220 (emphasis added). The use of the word "moreover" would seem to indicate that the court was announcing an additional basis for subjecting Aquitaine to possible $10 \mathrm{~b}-5$ liability.
} 
court's finding that the defendants were guilty of deceiving the stockholders of Banff under the Pappas v. Moss ${ }^{46}$ rationale. Pappas involved a stockholder derivative action against majority stockholders who, in their capacity as sole directors, voted to sell to themselves a large block of authorized but unissued stock at less than its current market value. The Third Circuit, in granting 10b-5 relief, found the requisite deceit

by viewing this fraud as though the 'independent' stockholders were standing in the place of the defrauded corporate entity at the time the original resolution authorizing the stock sales was passed. ${ }^{47}$

Since for most state law purposes, corporate directors, as agents of the corporation, are considered to be the corporation, their knowledge is imputed to the corporation..$^{48}$ Following this rationale to its logical conclusion, therefore, would mean that the directors' knowledge of their breach of fiduciary duty would be imputed to the corporation and consequently there could be no deception of the corporation by its directors for merely failing to reveal their breaches of duty. The Schoenbaum court's substitution of the stockholders for the corporate entity would seem to solve this conceptual problem; failure to reveal a breach of fiduciary duty to the stockholders in connection with the purchase or sale of securities would constitute the requisite material omission for $10 \mathrm{~b}-5$ violation. ${ }^{49}$

\section{Significance OF THE Schoenbaum DeCision}

Although the Schoenbaum majority cites the Ruckle dicta that a corporation may be "deceived" by its entire board of directors, the court's ruling as to the potential liability of Aquitaine and the Banff directors would seem to effectively eliminate the corporatedeception requirement in cases involving the purchase or sale of a coporation's securities by its directors when the beneficiary of the transaction is in a position to influence the directors. By allowing the plaintiff in Schoenbaum to pursue his derivative action at least through the discovery stage-and perhaps through trial-on the

* 393 F.2d 865 (1968).

"Id. at 869 (emphasis added).

4* 3 W. Fletcher, Private Corporations $\S \S 790,819$ (perm. ed. 1965); Restatement (SECOND) OF AGENCY § 282(1)(1958).

" See note 57 infra and accompanying text. 
strength of allegations amounting to mere circumstantial evidence that the defendants might have been influenced to act against the corporation in approving a sale of stock for -inadequate consideration, the Second Circuit would seem to be diluting the "deceit" requirement of $10 \mathrm{~b}-5$ to the point of abandonment. ${ }^{50}$ The plaintiff's allegation of facts amouniting to a breach of fiduciary duty coupled with the fact that the beneficiary of the directors' wrongdoings was in a position to influence the directors was sufficient to carry the conspiracy claim to the discovery stage, despite the plaintiff's inability to rebutt the defendants' summary judgments affidavits of denial. The dissenting judges in Schoenbaum criticize the majority's ruling on the grounds that allowing such relief under $10 \mathrm{~b}-5$ would be an open invitation for owners of a few shares of stock to give full rein to their imaginations in bringing harassment suits against corporate directors. ${ }^{51}$ Although the fear of such suits is of valid judicial concern, this apprehension would seem to be more than counterbalanced by the possibility of dwarfing the policy of $10 \mathrm{~b}$ 5 -the protection of the investing public. ${ }^{52}$ The Schoenbaum majority's granting of discovery evidences the court's concern that, given a factual situation like that alleged by the Schoenbaum plaintiff, it would better serve the policy of $10 \mathrm{~b}-5$ to allow him to explore the possibility of a scheme to defraud than to cut off actions by such plaintiffs for fear of the blackmail problems of strike suits.

The Second Circuit, however, has not abandoned altogether the Birnbaum-Maytag corporate-deception requirement. In dismissing Paribas as a defendant and in failing to discuss the liability of the Banff directors in connection with the sale of treasury stock to Paribas, the Second Circuit was seemingly requiring that the

\footnotetext{
${ }^{30}$ In finding "fraud" without deceit the Schoenbaum court was no doubt considering the special type of "equitable fraud" arising from breaches of trust by fiduciaries. See SEC v. Capital Gains Research Bureau, Inc., 375 U.S. 180 (1963). Clause (c) of 10b-5 which makes unlawful the commission of acts which operate "as a fraud or deceit" suggests that fraud without the common law element of deceit is also proscribed. 17 C.F.R. $\$ 240.10$ b.5 (emphasis added).

$\because 405$ F.2d at 221.

${ }_{32}$ Presidential Message, S. Rep. No. 792, 73rd Cong., 2d Sess. 1-2 (1934); see Cooper v. North Jersey Trust Co., 226 F. Supp. 972 (S.D.N.Y. 1964); New Park Mining Co. v. Cranmer, 225 F. Supp. 261 (S.D.N.Y. 1963); Pettit v. Am. Stock Exch., 217 F. Supp. 21 (S.D.N.Y. 1963).
} 
plaintiff allege more than a simple breach of fiduciary duty in order to impose 10b-5 liability, at least on the beneficiary of the transaction. ${ }^{53}$ Whereas the court was willing to allow the plaintiff to pursue his action beyond the summary judgment stage when he was able to allege a stock transaction benefiting a party in a position to influence the directors such as the majority shareholder, the Schoenbaum majority was unwilling to allow the same relief against a purchaser where the plaintiff could allege only a breach of fiduciary duty unconnected with any facts suggesting a conspiracy or undue influence of the corporate fiduciaries by the recipient of the stock. The plaintiff failed to state a ground for $10 \mathrm{~b}-5$ relief as to the Paribas transaction by his failure to allege facts which tended to show that Paribas, through ownership of stock or otherwise, ${ }^{54}$ was able to bring pressure on Banff directors to sell the corporation's stock for less than adequate consideration. In the absence of such an allegation, the plaintiff is not entitled to subject the defendant purchaser to the expense of discovery procedures and the plaintiff must seek any redress due him by an action under state law against the corporate directors for their waste of corporate assets. ${ }^{55}$ The Second Circuit would seem to be adhering to a test for gauging 10b-5 applicability against the purchaser which requires not only an allegation of a breach of duty by corporate fiduciaries but also an allegation of at least circumstantial evidence that the transaction resulted from a conspiracy or was negotiated at less

3 The dismissal of Paribas clearly indicates that the Second Circuit was requiring more than the allegation of a mere breach of fiduciary duty in order to impose $10 \mathrm{~b}-5$ liability on an outside beneficiary of the breach. The court's failure to discuss the potential $10 \mathrm{~b}-5$ liability of the corporate directors in connection with the Paribas transaction, however, is not to be taken as a clear indication that the court was exonerating the directors. Because of the court's ruling as to the corporate officers and Aquitaine, it is possible that these defendants might face discovery as to their activity and motivation in the Paribas transaction upon remand to the lower court. Under the Entel $v$. Allen test, see note 30 supra and accompanying text. the trial court might very well impose $10 \mathrm{~b}-5$ liability on the corporate direclors in connection with their unrevealed breach of state law fiduciary duty in the sale of treasury stock to Paribas.

"The court gives no indication of what type of activity would come within the "or otherwise" language. Presumably the court is alluding to any activity-i.e.. bribery or blackmail - that might be used to gain an overbearing influence on the corporate fiduciaries.

" For an examination of the various remedies available under state blue-sky law, see $L$. Loss \& 1:. Cowett. Blue Sky Law 129-71 (1958); 3 L. Loss, Securities Regulation 1631-1682 (2d ed. 1961, Supp. 1962). For an examination of common law remedies, see A. Bronberg. Securities Law: FraUd-SEC Rule 10b-5, $\$ 2.7(1)$, at 55 (1968). 
than arm's length. ${ }^{56}$ The Entel $v$. Allen ${ }^{57}$ conclusion that $10 \mathrm{~b}-5$ now is applicable to all undisclosed breaches of state law fiduciary duty, therefore, would seem to be overbroad, ${ }^{58}$ and $10 \mathrm{~b}-5$ must still be interpreted as not applying as against purchasers to those breaches of duty by corporate fiduciaries where the transaction in securities has been negotiated at arm's length..$^{59}$

The Second Circuit's citation of Pappas v. Moss ${ }^{60}$ with its theory of corporate-deception by substitution of the stockholders for the corporate entity, however, does raise the question of how this fictional device will be applied in future $10 \mathrm{~b}-5$ cases. ${ }^{61} \mathrm{By}$ finding deceit in the directors' failure to disclose their breach of fiduciary duty to the stockholders, the Pappas rationale could be applied to situations like the Paribas transaction as well as to the Aquitaine transaction..$^{2}$ Admittedly Pappas was cited by the Schoenbaum court only as an additional ground for the imposition

\footnotetext{
so In requiring the allegation of more than a breach of fiduciary duty in order to subject an outside purchaser to 10b-5 liability, the Second Circuit would seem to be turning to a scienter test in determining 10b-5 culpability. The common law deceit requirement of scienter has not been applied uniformly to $10 \mathrm{~b}-5$ situations. See note 18 supra and accompanying text. The cases which have discussed the scienter requirement in relation to $10 \mathrm{~b}-5$ actions against corporate officers have varied in their outcome. Compare, e.g., Ellis v. Carter, 291 F.2d 270, 274 (9th Cir. 1961) (no scienter required) with Weber v. C.M.P. Corp., 242 F. Supp. 321 (S.D.N.Y. 1965) (scienter required). Whereas there would seem to be legitimate reasons to abandon the scienter requirement as to corporate insiders, see Note, Fiduciary Suits Under Rule 10b-5, 1968 DUKE L.J. 791, 804, the requirement that the 10b-5 plaintiff at least allege circumstantial evidence of an outsider's scienter would be a means of limiting 10b-5 actions against potential defendants who do not occupy a position from which to takc advantage of the corporation.

57270 F. Supp. 60 (S.D.N.Y. 1967).

ss It could be argued that Entel recognized the necessity for some conspiracy or conflict of interest since, under traditional theories of imputed knowledge, breaches of duty involving such conflicts would be "undisclosed," and therefore subject to 10b-5 liability. See note 30 supra and accompanying text. This same rationale could be used under the Schoenbaum rule in the suit against the corporate directors.

5o Liability of the directors for such breaches might still be maintained, since it is unclear how the Schoenbaum court will deal with the directors as to the Paribas transaction. It may be that a Paribas-type defendant, even if not conspiring or excrcising undue influence, would be held liable for knowingly participating in the breach.

co 393 F.2d 865 (3d Cir. 1968).

${ }^{81}$ See Notc, Rule 10b-5 Corporate Mismanagement Cases: Who Must Deceive Who? 63 Nw. U.L. Rev. 477, 492 (1968), for an analysis of the Pappas ruling and the implications of its fictional theory of corporate deception.

${ }^{82}$ The limitation of liability, under the Schoenbaum rationale, to cases involving unrevealed breaches of fiduciary duty in connection with the fiduciaries' purchase or salc of the managed corporation's securities would seem to be necessitated, absent a situation
} 
of liability on Aquitaine and the Banff directors. ${ }^{63}$ However, unless future decisions limit the Pappas ruling to situations in which the beneficiary of an undisclosed breach of duty is in a position to conspire with or influence directors, then the shareholder substitution theory could itself be used to establish 10b-5 liability whenever there is a breach of state law fiduciary duty undisclosed to shareholders. If the courts must resort to fictionalized theories of corporate deception, it would seem that the panel court's theory of imputed knowledge with the adverse interest exception could better be used to limit $10 \mathrm{~b}-5$ actions to those cases involving something more than mere breach of fiduciary duty. Whereas, under Pappas, the stockholders theoretically would be deceived whenever the directors concealed their breach of fiduciary duty, the imputed knowledge test could be used to impute the directors' knowledge of their breach of duty to the corporation unless the plaintiff could allege (1) that the directors acted out of a conflict of interest or (2) that, because of the position of influence occupied by the beneficiary of the transaction, there is a strong possibility that the transaction was not negotiated at arm's Iength. It should be noted, however, that any fictional theory of deception can constitute a "trap for the unwary." "64 Therefore, it probably would be best to abandon the use of such fictions and either to admit that $10 \mathrm{~b}-5$ will be. applied against purchasers in situations involving traditional

requiring stockholder approval, by the iraditional rule that corporate directors have no duty to make the corporation's everyday stock transactions known to the stockholders. See R. Baker \& W. Cary, Corporations 94, 266, 531 (3d ed. 1959); Note, Fiduciary Suits Under Rule $10 b-5,1968$ DUKE L.J. 791, 814 \& n.108. Many corporations today hold stock in other corporations; these holdings are usually investment stocks and do not represent a controlling interest in the other corporations. If the directors were to vote to purchase or sell such stock holdings, it is doubtful whether the Schoenbaum rationale could be used to impose liability on them for any breach of fiduciary duty connected with such a transaction. The breach of fiduciary duty situation, however, might be interpreted by subsequent courts as coming within the "special circumstances doctrine" of Strong v. Repide, 213 U.S. 419 (1909). The Repide court ruled that under "special circumstances" the directors owe a duty of revelation directly to the stockholders. If the courts were to adopt the view that a breach of fiduciary duty in connection with any stock transaction carried on by them constituted such a "special circumstance" that the directors owed it to the stockholders to reveal their activities, then, for all practical purposes, the scope of $10 \mathrm{~b}-5$ would be extended to cover all transactions in which the directors breached their fiduciary duty since corporate fiduciaries are very unlikely to reveal their breaches of duty to the stockholders.

- See note 45 supra and accompanying text.

4405 F.2d at 215. 
breaches of fiduciary duty $y^{65}$ or to limit the Schoenbaum ruling to permit 10b-5 fiduciary claims to go to the discovery stage only when the beneficiary of the transaction is in a position to conspire with or influence the fiduciary. Depending upon the results of discovery and the evidence otherwise accumulated, the court should also consider allowing a full trial in order to evaluate the evidence of the defendants if, ultimately, it is their credibility that is on trial.

o The Schoenbaum panel dissenter stated: "What we have here then is a scheme by which the directors of Banff gave to the controlling stockholder . . . some millions of dollars worth of the corporation's property. A plainer case of fraud would be hard to find." 405 F.2d at 215 (emphasis added) (footnote omitted). The Schoenbaum dissenter was plainly advocating the extension of $10 \mathrm{~b}-5$ to cover situations involving mere breach of fiduciary duty. 